\title{
Sistem Hisab Awal Bulan Kamariah Dr. Ing. Khafid dalam Program Mawaiqt
}

\author{
Eni Nuraeni Maryam \\ eninuraenimaryam@gmail.com
}

\begin{abstract}
Abstrak
Perbedaan hari raya yang kerap terjadi di Indonesia membawa hikmah tersendiri bagi perkembangan ilmu falak. Di samping karena adanya perbedaan sikap terhadap laporan hasil rukyat pada saat itu, disebabkan pula oleh adanya perbedaan hasil hisab yang berkembang di Indonesia. Oleh sebab itulah orang-orang yang berkecimpung dalam dunia astronomi mulai menaruh perhatiannya terhadap perhitungan-perhitungan ilmu falak, khususnya perhitungan awal bulan Qamariah. Dalam kesempatan ini muncul program-program software yang menyiapkan data sekaligus melakukan perhitungan, sehingga program ini dirasa lebih praktis dan lebih udah bagi pemakainya. Program-program itu diantaranya "Falakiyah Najmi'oleh Nuril Fuad pada tahun 1995, program "Badiatul Misal'tahun 2000 dan program "Ahillah'tahun 2004 oleh Muhyiddin Khazin, program "Mawâqit Versi 2001" oleh Khafid pada tahun 2001. Mayoritas program diciptakan oleh para ahli astronomi maupun falak. Akan tetapi program "Mawâqit" diciptakan oleh Dr. Ing. Khafid dengan background keilmuannya yang merupakan seorang ahli geodesi. Lalu bagaimana implementasi pemikiran Dr. Ing. Khafid mengenai penentuan awal bulan Qamariah yang dituangkan dalam sebuah program yang bernama "Mawâqit".

Kata Kunci : Awal Bulan kamariah, Mawâqit, Dr. Ing. Khafid
\end{abstract}

\section{A. Pendahuluan}

Penentuan awal bulan Qamariah sangat penting artinya bagi segenap kaum muslimin, sebab banyak ibadah dalam Islam yang pelaksanaannya dikaitkan dengan perhitungan bulan Qamariah. Di antara ibadah-ibadah itu adalah shalat Idul Adha dan Idul Fitri, shalat gerhana bulan dan matahari, puasa Ramadhan dengan zakat fitrahnya, haji dan sebagainya. Demikian pula hari-hari besar dalam Islam, semuanya diperhitungkan menurut perhitungan bulan Qamariah. ${ }^{1}$

Sebenarnya, secara teknis ilmiah, posisi dan gerakan benda-benda langit sudah dapat dihitung, yaitu dengan ilmu astronomi modern dan bantuan komputer yang sangat teliti. Jangankan penampakan hilal yang sangat biasa dan selalu terjadi setiap bulan, perhitungan gerhana bulan maupun matahari yang relatif jarang pun bisa diperkirakan melalui perhitungan yang sangat teliti. Bahkan, soal yang jauh lebih rumit, seperti peristiwa langka berupa

${ }^{1}$ Badan Hisab dan Rukyat Departemen Agama, Almanak Hisab Rukyat, Jakarta: Proyek Pembinaan Badan Peradilan Agama Islam, 1981, h. 98. 
penampakan komet $^{2}$ yang terjadi setiap puluhan tahun bahkan ratusan tahun sekali, bisa diperhitungkan dengan baik. ${ }^{3}$

Dewasa ini metode hisab telah menggunakan komputer dengan tingkat presisi $^{4}$ yang jauh lebih tinggi dan akurat. Berbagai perangkat lunak (software) yang praktis juga telah ada. ${ }^{5}$ Bahkan dengan banyaknya program komputer, siapapun yang bisa mengoperasikannya, dengan mudah dapat menghitung posisi bulan dan matahari. Masalahnya, tidak semua orang mengerti arti angka dalam penentuan awal bulan Qamariah, khususnya dalam penentuan awal Ramadhan, Idul Fitri dan Idul Adha.

Kini, dengan metode astronomi yang sama, bahkan dengan program komputer, hasil hitungan pasti akan sama. Tidak peduli siapa yang menghitung, apakah Muhammadiyah, NU, Persis, atau orang awam. Terlalu naïf, ada yang merasa hasil hisab-nya lebih unggul dan seolah metodenya beda dengan metode ormas lain yang menggunakan rukyat. Padahal tidak ada bedanya, semua ormas bisa menghitung dengan hasil yang sama.

Dengan kemajuan teknologi yang didukung perangkat komputer modern, hasil hisab/rukyat yang dilakukan umat Islam dari belahan bumi lain dapat diketahui dengan cepat atau bahkan dalam hitungan milidetik oleh umat Islam di belahan bumi lainnya.

Diantara program-program komputer berbasis astronomi modern yang mendukung penentuan awal bulan Qamariah adalah Jean Meeus, Almanac Nautica, Astronomical Almanac, Mawâqit, Ascript, Astro Info, Starrynight, dan banyak software-software lainnya. Sistem hisab dalam program-program tersebut memiliki tingkat ketelitian yang tinggi sehingga dikelompokkan ke dalam High Accuracy Algorithm.

Di antara kesekian pemrograman komputer berbasis astronomi modern yang mendukung penentuan awal bulan Qamariah tersebut, penulis akan mengkaji Program Mawâqit yang merupakan implementasi dari hasil pemikiran Dr. Ing. Khafid.

Dr. Ing. Khafid adalah seorang ahli geodesi ${ }^{6}$ yang bekerja di Pusat Pemetaan Dasar Kelautan dan Kedirgantaraan Badan Koordinasi Survey dan Pemetaan Nasioanl (Bakosurtanal) ${ }^{7}$ Cibinong Bogor.

Para ahli astronomi menyatakan bahwa bentuk bumi adalah bulat. Hal tersebut terlihat dari rumus segitiga bola yang digunakan dalam penentuan awal bulan Qamariah. Sedangkan menurut ilmu geodesi, bentuk bumi tidaklah bulat pepat akan tetapi ellips (geoid).

Dengan background keilmuan Dr. Ing. Khafid yang bukan astronomi maupun ilmu falak melainkan geodesi, penulis ingin menelusuri salah satu software aplikasi falak yang terdapat dalam program Mawâqit khususnya mengenai sistem hisab awal bulan Qamariah.

\section{B. Biografi Intelektual Dr. Ing. Khafid}

${ }^{2}$ Komet adalah anggota tata surya yang berwujud gas dan menarik pandangan jika kebetulan ada di dekat matahari. Lintasan komet mengelilingi matahari berbentuk lonjong. Makin dekat dengan matahari makin menonjol ekornya, yang tak lain adalah gas mengembang. Lihat Iratius Radiman, dkk, Ensiklopedi Singkat Astronomi dan Ilmu Yang Bertautan, Bandung: Penerbit ITB, 1980, h. 50.

${ }^{3}$ Farid Ruskanda, 100 Masalah HIsab dan Rukyat Telaah Syariah, Sains, dan Teknologi, Jakarta: Gema Insani Press, 1996, h. 33.

${ }^{4}$ Presisi adalah ketelitian. Lihat Pius A. Partanto dan M. Dahlan Al Barry, Kamus Ilmiah Populer, Surabaya: Arkola, 1994, h. 623.

${ }^{5}$ Encup Supriatna, Hisab Rukyah dan Aplikasinya (Buku Satu), Bandung: Refika Aditama, Cet. Ke-1, 20017, h. 1 .

${ }^{6}$ Geodesi merupakan ilmu mengenai ukuran dan bentuk bumi serta metode untuk mengetahui ukurannya. Lihat Iratius Radiman, dkk, Ensiklopedi Singkat Astronomi dan Ilmu Yang Bertautan, h. 35.

${ }^{7}$ Sekarang Bakosurtanal berganti nama menjadi Badan Informasi Geospasial (BIG). 
Khafid, lahir di Demak, 4 Maret 1967. Sebagian besar masa kecilnya dihabiskan di Demak. Sekolah di SDN Kadilangu I Demak, SMP Negeri II Demak, dan SMA Negeri I Demak. Khafid baru meninggalkan Demak pada tahun 1987 setelah menerima beasiswa OFP (Offersis Felope Program) yang disponsori oleh BJ. Habibi. Khafid merupakan satu dari 250 penerima beasiswa tersebut yang dikirim ke berbagai Negara seperti Perancis, Jerman, Belanda, Amerika, Jepang, Austria dan Negara lainnya yang kemudian akan ditempatkan di beberapa lembaga, diantaranya LIPI (Lembaga Ilmu Pengetahuan Indonesia), Badan Meteorologi dan Fisika (BMKG), Badan Informasi Geospasial (BIF), Badan Pengkajian dan Penerapan Teknologi (BPPT), Lembaga Penerbangan Antariksa Nasional (LAPAN), dan lembaga lainnya.

Sesuai dengan minatnya kepada teknik informatik, Khafid memilih jurusan Teknik Informatika ke Jepang, akan tetapi nasib berkata lain. Khafid mendapatkan jatah beasiswa ke Belanda dengan jurusan Teknik Geodesi sesuai dengan penempatannya nanti di Bakosurtanal (sekarang BIG). Karena pada awalnya Khafid memang berkeinginan untuk mempelajari teknik informatika, meskipun sekolah jurusan teknik geodesi tetapi dia senang mengotak-atik komputer yang pada akhirnya menghasilkan macam-macam software, salah satu diantaranya Mawâqit.

Lulus SMA (1987) dia kemudian melanjutkan program S1 di Teknik Geodesi Universitas Delft Belanda. Karena program S1 dan S2-nya merupakan satu paket, program S2 pun ditempuhnya di Universitas yang sama. Program sarjana dan magisternya diselesaikan dalam kurun waktu 6,5 tahun. Kemudian Khafid melanjutkan program Doktornya di Universitas Teknik Munchen Jerman. ${ }^{8}$

Bersamaan dengan masuknya Khafid menjadi anggota Badan Hisab Rukyat Pusat pada tahun 2001, disanalah program Mawâqit mulai dikenal. Tahun 2006 Khafid dimintai kesediaannya oleh Rois PBNU, KH. Ghozali Masruri, untuk menjadi anggota Litbang LFPBNU.

Saat ini Khafid bekerja di Badan Informasi Geospasial (BIG). Selain menjadi anggota Badan Hisab Rukyat nasional mewakili BIG, dia juga menjadi salah satu tim penyusun Sub Misi Landas Kontinental Indonesia yang dikirim ke PBB. Hal ini terkait dengan batas wilayah Indonesia yang dimungkinkan untuk diperluas, dimana dia harus membuktikan data-datanya dengan menyusun data taktis untuk dikirim ke PBB. ${ }^{9}$

\section{Karya-karya Dr. Ing. Khafid}

Mawâqit merupakan salah satu software karya Khafid yang berasal dari kegemarannya terhadap teknik informatika dan keinginan untuk menyatukan perbedaan penentuan awal bulan Qamariah yang terjadi di sekelilingnya, khususnya di antara teman-temannya yang berasal dari berbagai Negara, seperti Maroko, Mesir Suriname, Turki, dan Negara lainnya. Berdasarkan perbedaan tersebut, Khafid merasa tertarik untuk mempelajari ilmu falak. ${ }^{10}$ Dengan keahliannya di bidang teknik informatika, Khafid dkk berhasil menciptakan software penentuan awal bulan Qamariah yang diberi nama Mawâqit 1.0.

Ketika duduk di bangku kuliah, dia lebih banyak mempelajari Teknik Satelit Altimetri (mengukur permukaan air laut dari satelit) untuk memprediksi gunung bawah laut, kedalaman laut, naik turunnya air laut, dan sebagainya. Sesuai dengan jurusannya tersebut, dia menghasilkan software pemrosesan data altimetri, software untuk menghitung geoid, dan software-software lainnya. Mawâqit adalah satu-satunya software hisab rukyat karyanya.

\footnotetext{
${ }^{8}$ Wawancara dengan Dr. Ing. Khafid di Hotel Nalendra Cihampelas Bandung pada tanggal 28 Juli 2010.

${ }^{9}$ Wawancara dengan Dr. Ing. Khafid via Email pada 12 Oktober 2010.

${ }^{10}$ Wawancara dengan Dr. Ing. Khafid di Kantor Pascasarjana UIN Walisongo Semarang pada 8 Mei 2010.
} 
Diantara semua software buatannya, software yang cukup besar adalah Mawâqit dan software Pemrosesan Data Altimetri.

Karya lain yang berbentuk buku adalah buku formal (tidak diperjualbelikan di pasaran melainkan untuk dikirimkan ke PBB), di antaranya adalah buku laporan survey. Adapun buku hisab rukyat karya Khafid hanya Buku Garis Tanggal Kalender Islam yang berisi tentang kalender Qamariah, garis tanggal Internasional, problematika penentuan awal bulan kalender Islam, penentuan awal bulan di Saudi Arabia, peran ilmu astro-geodesi dalam penanggalan Qamariah dan penelitian perhitungan penentuan awal bulan Qamariah. ${ }^{11}$

\section{Pemikiran Dr. Ing. Khafid tentang Hisab Awal Bulan Qamariah Program Mawaaqit}

Geodesi merupakan suatu cabang ilmu yang mempelajari ilmu ukur tanah (bumi). Sebagai seorang ahli geodesi, Khafid tidak mempelajari ilmu astronomi secara mendalam ketika di bangku kuliah. Hal ini dikarenakan di fakultas geodesi tidak ada mata kuliah yang mempelajari astronomi secara khusus, yang ada mata kuliah Geodetik Astronomi yang hanya mempelajari masalah positioning (tempat). Meskipun demikian, Khafid telah berhasil menciptakan sebuah program software) yang merupakan aplikasi dari ilmu falak, yaitu Mawâqit.

Perbedaan penentuan awal bulan Qamariah yang terjadi di antara Khafid dkk menjadi motivasi penyatuan penentuan awal bulan Qamariah di Belanda. Pada tahun 1992/1993 ICMI orsat Belanda mensponsori penelitian perhitungan awal bulan Qamariah dengan metode astronomi modern. Pelaksanaan kegiatan penelitian itu dilakukan oleh beberapa siswa yang sedang bertugas di Delft Belanda. Adapun peneliti-peneliti tersebut adalah Khafid, Wakhid Sudiantoro Putro, Dadan Ramdani, Ade Komara Mulyana, Adi Junjunan Mustafa (dari Bakosurtanal) dan Kiki Yaranusa (dari IPTN). ${ }^{12}$

Kegiatan penelitian ini menghasilkan software Mawaqit 1.0 yang ditulis dalam bahasa program PASCAL dalam DOS. Tanggapan positif dari kalangan masyarakat muslim Indonesia baik yang berada di mancanegara maupun yang ada di dalam negeri, bahkan banyaknya tanggapan dari masyarakat muslim dari Negara lain memberikan bukti bahwasanya penelitian lebih lanjut sangat diperlukan. Pada periode tahun 1994 sampai 1996, Khafid dan Fahmi Amhar dari Bakosurtanal melakukan perbaikan-perbaikan program Mawâqit sampai pada versi 1.3.

Bersamaan dengan perkembangan teknologi komputer, terutama didorong dengan munculnya sistem operasi baru Windows 95 dan Windows NT dan juga teknologi internet, peneltian lebih lanjut tentang perhitungan kalender Qamariah dilakukan oleh Khafid. Sebagai hasilnya dipublikasikan serangkaian versi software Mawâqit dan Mawâqit 32++ yang ditulis dengan bahasa program $\mathrm{C} / \mathrm{C}++$ berjalan dalam sistem operasi Windows 95/Windows NT, Mawâqit 96.04 versi internet ditulis dengan Java. Selanjutnya muncul Mawâqit 2000 yang sudah dilengkapi dengan modul-modul analisis yang diperlukan. Saat ini Mawâqit yang teraktual adalah versi 2001.

Dalam program penentuan awal bulannya, Khafid menggunakan teori algoritma dengan ketelitian yang sangat tinggi yaitu VSOP87. Variattions Seculaires des Orbites Planetaires Theory (VSOP) ini disusun oleh Bretagnon pada tahun 1982 dan disempurnakan oleh Bretagnon

${ }^{11}$ Wawancara dengan Dr. Ing. Khafid di Hotel Nalendra Cihampelas Bandung pada tanggal 28 Juli 2010.

12 Khafid, Petunjuk Pemakaian Program Mawaqit Versi 2001, Disampaikan pada Kuliah Umum dan Penutupan Kursus Hisab Rukyat Pengadilan Tinggi Agama Surabaya Tanggal 4-5 September 2005 dengan topik: Komputerisasi Program Hisab Rukyat. 
dan Francou pada tahun 1987 sehingga sering disebut VSOP87. ${ }^{13}$ Jean Meeus menyatakan bahwa dengan teori dan algoritma VSOP87 akurasi yang didapatkan adalah lebih baik dari $0.01 \%$. ${ }^{14}$

Pada Mawâqit versi 1.0 yang ditulis dalam bahasa program PASCAL dan DOS hingga Mawâqit versi 2000 Khafid menggunakan algoritma Meeus dengan kisaran ketelitian sekitar 1", akan tetapi pada Mawâqit versi 2001 Khafid mengkombinasikan algoritma Meeus dengan VSOP87 yang ketelitiannya mencapai 0.01 ”.

Khafid menggunakan teori dan algoritma VSOP87 untuk menetukan koordinat matahari yang meliputi lintang matahari, ${ }^{15}$ bujur matahari, ${ }^{16}$ jarak matahari dari bumi, deklinasi matahari, ${ }^{17}$ asensio rekta, ${ }^{18}$ tinggi matahari dari horizon, ${ }^{19}$ dan azimuth matahari. ${ }^{20}$

Sedangkan untuk menetukan posisi bulan, Khafid menggunakan algoritma Jean Meeus yang meliputi lintang bulan, bujur bulan, jarak bulan dari bumi, deklinasi bulan, asensio rekta, tinggi bulan dari horizon, dan azimuth bulan, umur bulan, fase illuminasi, ${ }^{21}$ elongasi. ${ }^{22}$

Algoritma Meeus sendiri sebenarnya merupakan reduksi dari algoritma VSOP87 yang lengkap. Dari ribuan suku koreksi dalam algoritma VSOP87, maka yang diperhitungkan adalah sekitar ratusan suku-suku yang besar dan penting dalam algoritma Meeus ini. ${ }^{23}$

${ }^{13}$ Dhani Herdiwijaya, Makalah disampaikan pada acara Diklat Nasional Pelaksana Rukyat Nahdatul Ulama, oleh Lajnah Falakiyah NU di Masjid Agung Jawa Tengah, 19 Desember 2006.

14 http://www.eramuslim.com/syariah/ilmu-hisab/posisi-matahari-algoritma-meeus.htm. Diakses pada 9 Desember 2010.

15 Lintang matahari/lintang ekliptika dikenal dalam bahasa Indonesia dengan lintang astronomi yang dikenal pula dengan 'ardlusy syams. Data ini adalah jarak titik pusat matahari dari lingkaran ekliptika. Lihat Direktorat Urusan Agama Islam dan Pembinaan Syariah Ditjen Bimbingan Masyarakat Islam, Ephemeris Hisab Rukyat, Departemen Agama RI, h. 3.

${ }^{16}$ Bujur matahari/ Bujur ekliptika dikenal dalam bahasa Indonesia dengan bujur astronomi yang dikenal pula dengan istilah Taqwim atau Thul yakni jarak matahari dari titik Aries (Vernal Equinox) diukur sepanjang lingkaran ekliptika. Ephemeris Hisab Rukyat, Departemen Agama RI, h. 3.

${ }^{17}$ Apparent Declination dikenal dalam bahasa Indonesia dengan deklinasi matahari yang terlihat (bukan matahari hakiki) atau yang dikenal dengan mail syams adalah jarak matahari dari equator. Ephemeris Hisab Rukyat, Departemen Agama RI, h. 3.

${ }^{18}$ Apparent Right Ascension dikenal dalam bahasa Indonesia dengan Asensio Rekta. Data ini adalah jarak matahari dari titik Aries diukur sepanjang lingkaran equator. Ephemeris Hisab Rukyat, Departemen Agama RI, h. 3.

${ }^{19}$ Ketinggian yang dalam astronomi dikenal dengan istilah altitude, yaitu ketinggian benda langit dihitung sepanjang lingkaran vertikal dari ufuk sampai benda langit yang dimaksud. Ketinggian benda langit bertanda positif (+) apabila benda langit ybs berada di atas ufuk, demikian pula bertanda negatif (-) apabila ia berada di bawah ufuk. Dalam astronomi biasanya diberi notasi $h$ (hight). Lihat Muhyiddin Khazin, Kamus Ilmu Falak, Jogjakarta: Buana Pustaka, Cet. Ke-1, 2005, h. 37.

${ }^{20}$ Azimuth matahari adalah busur matahari pada lingkaran horizon diukur mulai dari titik utara ke arah timur atau kadang-kadang diukur dari titik selatan ke arah barat. Dalam bahasa Arab disebut as-simt. Lihat Encup Supriatna, Hisab Rukyat dan Aplikasinya, Bandung: Refika Aditama, 2007, h. xi

21 Iluminasi adalah luas bagian bulan yang memancarkan sinar, dalam praktek perhitungan, harga maksimal iluminasi bulan adalah 1 (satu) yakni ketika terjadi bulan purnama. Lihat Muhyiddin Khazin, Kamus Ilmu Falak, h. 34 .

${ }^{22}$ Elongasi adalah sudut pada bumi yang dibentuk oleh garis hubung antara suatu planet dengan bumi. Elongasi $0^{\circ}$ ketika terjadi konjungsi; $90^{\circ}$ ketika pada kwartir pertama, $180^{\circ}$ ketika oposisi, dan $270^{\circ}$ ketika pada kwartir kedua. Lihat Muhyiddin Khazin, Kamus Ilmu Falak, h. 23.

${ }^{23}$ Dhani Herdiwijaya, Makalah disampaikan pada acara Diklat Nasional Pelaksana Rukyat Nahdatul Ulama, oleh Lajnah Falakiyah NU di Masjid Agung Jawa Tengah, 19 Desember 2006. 


\section{E. Penentuan Awal Bulan Menurut Kriteria Astro-Geodesi}

Untuk memprediksi visibilitas hilal, hal pokok yang harus diketahui adalah posisi bulan dan matahari terhadap bumi. Untuk itu setidaknya harus dipertimbangkan faktor-faktor astrogeodesi sebagai berikut: ${ }^{24}$

1. Konjungsi

Sebagai syarat mutlak nampaknya hilal adalah terjadinya ijtima'. Ijtima' artinya berkumpul atau bersama, yaitu posisi Matahari dan Bulan berada pada satu bujur astronomi. Dalam stronomi dikenal dengan istilah Conjunction (konjungsi). Para ahli astronomi murni menggunakan ijtima' ini sebagai kriteria pergantian bulan Qamariah, sehingga ia disebut pula dengan New Moon (bulan baru). ${ }^{25}$

Bulan baru dalam astronomi tidaklah sama dengan definisi bulan baru dalam kalender Qamariah. Bulan baru dalam astronomi adalah konjungsi yang terjadi serentak untuk seluruh dunia, akan tetapi belum tentu pada saat tersebut bulan dapat terlihat dengan mata. Sedangkan bulan baru dalam kalender Islam disebut dengan awal bulan Qamariah, tergantung pada kenyataan kenampakan bulan (hilal) pertama kali dari pengamat yang berada di bumi setelah terjadinya konjungsi. Kenampakan bulan sudah barang tentu tergantung juga pada lokasi atau posisi dimana pengamat berada di muka bumi. Hal inilah diantaranya yang dapat menyebabkan terjadinya perbedaan prediksi teramatinya hilal. Perbedaan atau selisih waktu tersebut dapat menyebabkan beda penanggalan satu hari.

Secara perhitungan astro-geodesi modern kapan terjadinya konjungsi dapat diperkirakan dengan ketelitian sampai beberapa detik. Contoh yang jelas adalah prakiraan terjadinya gerhana bulan atau gerhana matahari yang dapat dilakukan dengan ketelitian sampai bilangan beberapa detik.

\section{Peta Ketinggian Bulan}

Pada dasarnya dengan ilmu astro-geodesi, ketinggian bulan atau hilal dapat diperkirakan untuk berbagai tempat di seluruh belahan bumi. Adanya perhitungan yang akurat dan penyajian yang gamblang dalam bentuk peta akan sangat membantu analisis untuk keperluan prediksi kenampakan bulan. Peta semacam ini perlu dibuat di hari saat yang diduga hilal akan nampak. Di dalam peta, bisa kita lihat adakalanya satu wilayah mempunyai ketinggian bulan positif dan adakalanya negatif. Wilayah-wilayah yang mempunyai ketinggian bulan negatif sudah barang tentu dapat disimpulkan di wilayah tersebut tidaklah mungkin bulan akan nampak. Sedangkan untuk daerah-daerah yang mempunyai ketinggian positif masih perlu dianalisis lebih lanjut dengan gabungan data-data lainnya. ${ }^{26}$

\section{Peta Ketinggian Matahari}

Kenampakan bulan dari pengamat yang berada di bumi sangat dipengaruhi oleh sinar matahari. Di samping itu di saat-saat terjadinya hilal dimana intensitas pencahayaan bulan masih sangat rendah, cahaya matahari sangat berpengaruh dalam hasil pengamatan kenampakan bulan. Itulah sebabnya pengamatan kenampakan hilal harus dilakukan setelah matahari terbenam. Peta ketinggian matahari akan sangat membantu perhitungan kenampakan bulan dengan teliti. ${ }^{27}$

\footnotetext{
${ }^{24}$ Khafid, Petunjuk Pemakaian Program Mawaqit Versi 2001

${ }^{25}$ Muhyiddin Khazin, 99 Tanya Jawab Masalah Hisab dan Rukyat, Yogyakarta: Ramadhan Press, 2009, h.

${ }^{26}$ Khafid, Petunjuk Pemakaian Program Mawaqit Versi 2001, h. 18.

${ }^{27}$ Khafid, Petunjuk Pemakaian Program Mawaqit Versi 2001, h. 19.
} 70. 


\section{Peta Umur Bulan Saat Matahari Terbenam}

Terjadinya konjungsi saja tidak memberikan jaminan bahwa hilal pasti Nampak. Syaratsyarat berikutnya yang harus dipenuhi adalah umur bulan ${ }^{28}$ saat matahari terbenam. Informasi tentang umur bulan pada saat matahari terbenam inipun dapat disajikan dalam bentuk peta sebagai bahan analisis kenampakan hilal. ${ }^{29}$

\section{Peta Fase Pencahayaan Bulan}

Syarat yang harus dipertimbangkan untuk memperkirakan kenampakan hilal adalah fase pencahayaan bulan. Bisa jadi karena bulan sudah cukup fase pencahayaannya di saat syaratsyarat lain masih belum memenuhi kriteria yang ditentukan, namun dalam kenyataannya hilal sudah nampak atau terjadi sebaliknya. Informasi tentang fase pencahayaan bulan yang tergantung tempat dan waktu ini bisa dipetakan juga untuk membantu analisis prakiraan kenampakan hilal.

\section{Peta Jarak Waktu Terbenam antara Matahari dan Bulan}

Rukyat harus dilakukan sesaat setelah matahari terbenam sampai bulan terbenam. Jadi tidak mungkin mengamati hilal apabila pada hari melakukan rukyat ternyata bulan terbenam mendahului matahari atau dalam artian bulan masih di bawah ufuk. Jarak waktu matahari dan bulan terbenam yang terlalu pendek pun mempunyai tingkat kenampakan hilal yang sangat kecil. Kenampakan hilal dapat dikaitkan dengan jarak waktu terbenam antara matahari dan bulan terbenam, "semakin lama jangka waktunya semakin besar kemungkinan hilal dapat diamati". Komponen inipun informasinya dapat dituangkan dalam bentuk peta, karena dari kenyataan bahwa jarak terbenam antara matahari dan bulan juga tergantung letak geografis suatu tempat.

7. Overlay Antara Berbagai Topik Peta

Dari berbagai faktor-faktor yang disebutkan di atas dapat dilakukan overlay ${ }^{30}$ peta sesuai dengan definisi kenampakan bulan menurut kriteria astro-geodesi.

\section{F. Sistem Hisab Awal Bulan Qamariah Dr. Ing. Khafid dalam Program Mawâqit}

Mawâqit merupakan salah satu contoh program komputer yang berbasis astronomi modern. Metode yang digunakan dalam penentuan awal bulan program Mawâqit adalah menggunakan metode Hisab Haqiqi Kontemporer. ${ }^{31}$ Dimana sistem hisab ini menggunakan hasil penelitian terakhir dan menggunakan matematika yang telah dikembangkan.

${ }^{28}$ Umur Bulan didefinisikan sebagai hitungan waktu dengan epoch saat terjadinya konjungsi. Sebagai contoh: apabila hari ini terjadi konjungsi pada jam 15.00 WIB, dan matahari terbenam jam 18.00. Maka umur bulan saat matahari terbenam adalah 3 jam.

${ }^{29}$ Khafid, Petunjuk Pemakaian Program Mawaqit Versi 2001, h. 20.

${ }^{30}$ Overlay adalah lembaran penutup; lapisan atas; hamparan. Lihat John M. Echols dan Hasan Sadily, Kamus Inggris-Indonesia, Jakarta: Gramedia Pustaka Utama, Cet. Ke XXIV, 2000, h. 412.

${ }^{31}$ Yang termasuk klasifikasi Hisab Haqiqi Kontemporer adalah New Comb yang dipakai oleh Bidron Hadi, Almanac Nautika yang dikeluarkan oleh TNI AL Dinas Hidro Oseanografi Jakarta, The Astronomical Almanac yang diterbitkan Nautical Almanac Office, Astronomical Tables of Sun, Moon and Planets oleh Jean Meeus Belgia, Islamic Calender oleh Muhammad Ilyas dan Ephemeris oleh Badan Hisab Rukyah Depag. Lihat Sriyatin Shadiq, Perkembangan Hisab Rukyah dan Penetapan Awal Bulan Qamariah, dalam Muamal Hamidy (Editor), Menuju Kesatuan Hari Raya, Surabaya: Bina Ilmu, 1995, h. 67-68. 
Metodenya sama dengan metode Hisab Haqiqi Tahqiqi, ${ }^{32}$ hanya saja sistem koreksinya lebih teliti dan kompleks, sesuai dengan kemajuan sains dan teknologi. Rumus-rumusnya lebih disederhanakan sehingga untuk menghitungnya dapat digunakan kalkulator atau personal komputer. $^{33}$

Mawâqit menggunakan metode astro-geodesi dalam penentuan awal bulan Qamariahnya. Meskipun demikian rumus perhitungannya tetap menggunakan rumus astronomi (spherical trigonometry). Peran metode atro-geodesi adalah untuk memprediksi kenampakan bulan. Dengan kata lain, kapan hilal nampak dan dimana dapat diperhitungkan. ${ }^{34}$

Dalam perhitungannya ada beberapa koreksi terhadap ketinggian hilal, diantaranya:

a. Berbeda dalam melihat parallax/ikhtilaf al-mandzar.

Dengan koreksi ini berarti tinggi hilal diperhitungkan dari permukaan bumi tempat pengamat, bukan dari titik pusat bumi. Parallaks ini diformulasikan dengan besarnya suatu sudut antara dua garis yang ditarik dari benda langit ke titik pusat bumi dan garis yang ditarik dari benda langit ybs ke mata peninjau di permukaan bumi. Semakin jauh jaraknya semakin kecil harga parallaksnya. Begitu pula semakin tinggi posisi benda langit dari ufuk semakin kecil pula harga parallaksnya. ${ }^{35}$

b. Pembiasan Sinar (Refraksi)

Refraksi yaitu perbedaan antara tinggi suatu benda langit yang sebenarnya dengan tinggi benda langit itu yang dilihat sebagai akibat adanya pembiasan sinar. Refraksi terjadi karena sinar yang datang sampai ke mata kita telah melalui lapisan-lapisan atmosfer, sehingga sinar yang datang itu mengalami pembengkokan, padahal yang kita lihat adalah arah lurus pada sinar yang ditangkap mata kita. ${ }^{36}$

Dengan koreksi ini yang dihisab adalah tinggi melihat hilal, bukan tinggi nyata. Pada Mawâqit koreksi refraksi hanya diterapkan ketika matahari berada di atas ufuk. Jika hilal di bawah ufuk refraksi tidak diperhitungkan. Adapun refraksi di sekitar ufuk sebesar $0^{\circ} 34$ '.

Ketinggian hilal pada Mawâqit dihitung dari titik pusat bulan, sehingga semidiameter bulan tidak diperhitungkan. Begitupun dengan kerendahan ufuk tidak diperhitungkan, karena dalam Mawâqit ketinggian seluruh tempat dianggap $0 .{ }^{37}$

\section{G. Tingkat Akurasi Hisab Awal Bulan Qamariah dalam Program Mawâqit}

Dalam program penentuan awal bulannya, Khafid menggunakan sumber data dan algoritma dengan ketelitian yang sangat tinggi, yaitu VSOP87. Melihat dari teori dan algoritma

${ }^{32}$ Yang termasuk klasifikasi Hisab Hakiky Tahqiqi adalah al-Mathla'us Said fi Hisabil Kawakib al Rusydil Jadid karya Syeh Husain Zaid al-Misra, Al-Manahijul Hamidiyah karya Syeh Abdul Hamid Mursy Ghaisul Falaky, Muntaha Nataijul Aqwal karya Muhammad Hasan Asy'ari, Al-Khulasatul Wafiyah karya Zubaer Umar al-Jaelany, Badi'atul Mitsal karya Muhammad Ma'shum bin Ali, Hisab Haqiqi karya Muhammad Wardan DIpaningrat, Nurul anwar karya Noor Ahmad Shadiq bin Saryani, ittifaq Dzatil Bain karya Muhammad Zubaer Abdul Karim, lihat Sriyatin Shadiq, Perkembangan Hisab Rukyah dan Penetapan Awal Bulan Qamariah, dalam Muamal Hamidy (Editor), Menuju Kesatuan Hari Raya, h. 67.

${ }^{33}$ Ahmad Izzuddin, Fiqh Hisab Rukyah, Menyatukan NU dan Muhammadiyah dalam Penentuan Awal Ramadhan, Idul Fitri dan Idul Adha, Jakarta: Erlangga, 2007, h. 8.

${ }^{34}$ Khafid, Garis Tanggal Kalender Islam 1427 H, Cibinong: Badan Koordinasi Survey dan Pemetaan Nasional, 2006, h. 17.

${ }^{35}$ Muhyiddin Khazin, Ilmu Falak dalam Teori dan Praktek, Yogyakarta: Buana Pustaka, Cet. Ke-1, 2004, h. 138 .

\footnotetext{
${ }^{36}$ Muhyiddin Khazin, Ilmu Falak dalam Teori dan Praktek, h. 142.

${ }^{37}$ Wawancara dengan Dr. Ing. Khafid di Hotel Nalendra Cihampelas Bandung pada tanggal 28 Juli 2010.
} 
yang digunakan dengan ketelitian lebih baik dari 0.01", hisab awal bulan Qamariah Program Mawâqit dapat dikatakan cukup akurat.

Di samping itu bukti keakurasiannya dapat dilihat dari hasil hisab Program Mawâqit ketika dibandingkan dengan hasil hisab Ephemeris yang termasuk ke dalam High Accuracy Algorithm yang selama ini sering dijadikan pedoman pelaksanaan rukyat dalam penentuan awal bulan Qamariah.

Pada awalnya data yang dipakai oleh para astronom dalam perhitungan awal bulan Qamariah di Indonesia adalah data Almanac Nautika. Mengingat data Almanac Nautika itu hanya diterbitkan setiap tahun, sehingga apabila ingin melakukan perhitungan untuk dua tahun yang akan datang tentu mengalami kesulitan, sebab Almanac Nautica belum ada karena memang belum dikirim.

Ephemeris yang dikenal dengan "Hisab for Windows ver 1.0" merupakan salah satu program software data astronomis yang disusun pada tahun 1993 oleh Drs. Taufik beserta putranya atas biaya Departemen Agama RI. Software ini dibuat karena langkah perhitungan ilmu falak sampai periode ini dirasa panjang dan melelahkan, juga buku Almanak Nautika sering terlambat datang. Software ini hasilnya mirip dengan Almanak Nautika atau semacamnya. Kemudian pada tahun 1998, program ini disempurnakan dan berganti nama menjadi "Winhisab Versi 2.0” dengan hak lisensi pada Badan Hisab Rukyat Departemen Agama RI. Di antara isi program ini adalah data astronomis (Ephemeris) matahari dan bulan untuk keperluan perhitungan pengukuran arah kiblat, waktu-waktu shalat, awal bulan dan gerhana. Perhitungan yang menggunakan data dari program Winhisab ini dikenal juga dengan Sistem Ephemeris atau Sistem Ephemeris Hisab Rukyat. ${ }^{38}$

Berikut data hasil hisab Program Mawâqit dan Ephemeris Hisab Rukyat dalam penentuan awal bulan Ramadhan $1431 \mathrm{H}$ untuk Markaz Semarang dengan koordinat 6 ${ }^{\circ} 58^{\prime}$ LS dan $110^{\circ} 29^{\prime}$ BT dengan ketinggian $0 \mathrm{~m}$.

\begin{tabular}{|c|c|c|}
\hline \multirow[b]{2}{*}{ Hasil Hisab } & \multicolumn{2}{|c|}{ Sistem } \\
\hline & Ephemeris Hisab Rukyat & Mawâgit \\
\hline Ijtima’ & $\begin{array}{l}\text { Selasa, 10 Agustus } 2010 \\
\text { Pukul. 10:09:17 }\end{array}$ & $\begin{array}{l}\text { Selasa, } 10 \text { Agustus } 2010 \\
\text { Pukul. 10:08:01 }\end{array}$ \\
\hline Matahari terbenam & 17. 39. 09.33 WIB & 17. 39. 09 WIB \\
\hline Azimuth matahari & $285^{\circ} 32^{\prime} 20.00^{\prime \prime}$ & $285^{\circ} 32^{\prime} 19.00^{\prime \prime}$ \\
\hline Azimuth bulan & $281^{\circ} 23^{\prime} 03.70^{\prime \prime}$ & $281^{\circ} 22^{\prime} 58.00^{\prime \prime}$ \\
\hline Posisi hilal & $04^{\circ} 09^{\prime} 16.38^{\prime \prime} \mathrm{SM}$ & $04^{\circ} 09^{\prime} 20.38^{\prime \prime}$ \\
\hline Tinggi hilal & $02^{\circ} 06^{\prime} 27.03^{\prime \prime}$ & $02^{\circ} 07^{\prime} 06.89^{\prime \prime}$ \\
\hline
\end{tabular}

Ketidaksamaan hasil perhitungan itu terjadi mungkin karena:

1. Data koordinat (lintang dan bujur tempat observasi) yang digunakan tidak sama.

2. Koreksi-koreksi terhadap gerak bulan yang dimasukkan tidak sama.

3. Pangkal ukur perhitungan ketinggian hilal tidak sama. Ada yang menghitung ketinggian hilal dari ufuk haqiqi dan adapula yang menghitungnya dari ufuk mar' $i$.

4. Bagian hilal yang dihitung tidak sama. Ada yang menghitung ketinggian hilal dari ufuk sampai titik pusat hilal. Ada yang menghitung ketinggian hilal dari ufuk sampai piringan atas hilal dan ada yang menghitung ketinggian hilal dari ufuk sampai piringan bawah hilal. ${ }^{39}$

\footnotetext{
${ }^{38}$ http://prisdaba.blogspot.com

${ }^{39}$ Muhyiddin Khazin, 99 Tanya Jawab Masalah Hisab dan Rukyat, h. 83.
} 
Secara keseluruhan rumus-rumus yang digunakan dalam perhitungan awal bulan Qamariah Program Mawâqit sama dengan rumus perhitungan yang digunakan Ephemeris Hisab Rukyat, hanya saja ada beberapa turunan rumus yang berbeda, di antaranya rumus menghitung azimuth, dan refraksi.

Di samping itu, koreksi terhadap ketinggian hilal pada Program Mawâqit hanya terdiri dari dua macam, yaitu koreksi refraksi dan parallaks, berbeda dengan koreksi pada sistem Ephemeris HIsab Rukyat yang juga memperhitungkan kerendahan ufuk/dip. Hal ini disebabkan karena pada Mawâqit ketinggian semua tempat dianggap 0.

Perbedaan lain pada Mawâqit dan Ephemeris Hisab Rukyat adalah sumber data Ephemeris yang digunakan dalam Mawâqit menggunakan jam LMT (Local Mean Time), sedangkan Ephemeris HIsab Rukyat menggunakan jam GMT (Greenwich Mean Time).

Kemudian terdapat perbedaan data koordinat Program Mawâqit dengan data koordinat dari sumber lain. Misalkan koordinat kota Semarang, pada Mawâqit dituliskan bahwa koordinat kota Semarang adalah $6^{\circ} 58^{\prime} \mathrm{LS}$ dan $110^{\circ} 29^{\prime}$, sedangkan kebanyakan sumber lain menyatakan bahwa koordinat kota Semarang adalah $7^{\circ}$ 00' LS dan $110^{\circ} 24^{\prime}$ BT. Perbedaan tersebut kemungkinan disebabkan oleh karena Program Mawâqit belum dikoreksi kembali setelah versi terakhirnya yang dikeluarkan pada tahun 2001.

Program Mawâqit dalam penentuan awal bulan Qamariah tentunya memiliki kelebihan dan kekurangan. Kelebihannya antara lain:

1. Penentuan awal bulan Qamariah Program Mawâqit yang bersifat opsional memudahkan semua golongan untuk menyesuaikan kriteria penentuan awal bulan yang dikehendakinya untuk mengetahui kapan awal bulan Qamariah dimulai sejak jauh-jauh hari, terutama bulan-bulan yang ada kaitannya dengan ibadah umat Islam.

2. Program Mawâqit dilengkapi dengan peta kenampakan hilal dan data koordinat kota-kota besar di seluruh dunia, sehingga akan memudahkan pengguna untuk mengetahui kapan dan dimana hilal akan terlihat.

3. Tingkat ketelitian data yang digunakan dalam program Mawâqit cukup tinggi. Dengan teori dan algoritma VSOP87 akurasi yang didapatkan adalah lebih baik dari 0.01". sehingga hasil hisab Program Mawâqit bisa menghasilkan data yang akurat dan dapat dijadikan pedoman penentuan awal bulan Qamariah.

Adapun kekurangannya antara lain:

1. Program Mawâqit belum mencantumkan ketinggian tempat dalam perhitungan awal bulan Qamariah, ketinggian semua tempat dianggap 0 padahal ketinggian bulan dipengaruhi juga oleh ketinggian tempat.

2. Data koordinat kota-kota yang terdapat pada Program Mawâqit adalah data lama yang belum diperbaharui lagi selama 10 tahun, sehingga data-data tersebut memerlukan koreksi dengan data-data koordinat yang terbaru.

\section{H. Penutup}

Metode hisab awal bulan Qamariah Program Mawâqit adalah Hisab Haqiqi Kontemporer. Sistem hisab ini menggunkan hasil penelitian terakhir dan menggunakan metematika yang telah 
dikembangkan. Metodenya sama dengan metode Hisab Haqiqi Tahqiqi hanya saja sistem koreksinya lebih teliti dan kompleks, sesuai dengan kemajuan sains dan teknologi. Rumusrumusnya lebih disederhanakan sehingga untuk menghitungnya dapat digunakan kalkulator atau personal komputer.

Mawâqit menggunakan metode astro-geodesi dalam penentuan awal bulan Qamariah. Kaitannya dalam penentuan awal bulan Qamariah, metode astro-geodesi digunakan untuk memprediksi kenampakan bulan. Dengan kata lain, kapan hilal nampak dan dimana dapat diperhitungkan.

Program Mawâqit sendiri merupakan software yang dirancang sebagai alat bantu untuk mempermudah hisab awal bulan Qamariah. Mawâqit sifatnya opsional, dapat digunakan oleh ormas manapun baik NU, Muhammadiyah, maupun Persis. Tidak ada kriteria khusus yang dipakai Mawâqit dalam penentuan awal bulan Qamariah. Dengan sifatnya yang opsional, Mawâqit bisa di-set untuk kriteria Danjon, MABIMS, Imkan al-Rukyat, ataupun Wujud al-Hilal. 


\section{Daftar Pustaka}

Badan Hisab dan Rukyat Departemen Agama, Almanak Hisab Rukyat, Jakarta: Proyek Pembinaan Badan Peradilan Agama Islam, 1981.

Direktorat Urusan Agama Islam dan Pembinaan Syariah Ditjen Bimbingan Masyarakat Islam, Ephemeris Hisab Rukyat, Departemen Agama RI.

Echols, John M., dan Hasan Sadily, Kamus Inggris-Indonesia, Jakarta: Gramedia Pustaka Utama, Cet. Ke XXIV, 2000.

Herdiwijaya, Dhani, Makalah disampaikan pada acara Diklat Nasional Pelaksana Rukyat Nahdatul Ulama, oleh Lajnah Falakiyah NU di Masjid Agung Jawa Tengah, 19 Desember 2006.

Izzuddin, Ahmad, Fiqh Hisab Rukyah, Menyatukan NU dan Muhammadiyah dalam Penentuan Awal Ramadhan, Idul Fitri dan Idul Adha, Jakarta: Erlangga, 2007.

Khafid, Petunjuk Pemakaian Program Mawaqit Versi 2001, Disampaikan pada Kuliah Umum dan Penutupan Kursus Hisab Rukyat Pengadilan Tinggi Agama Surabaya Tanggal 4-5 September 2005 dengan topik: Komputerisasi Program Hisab Rukyat.

, Garis Tanggal Kalender Islam 1427 H, Cibinong: Badan Koordinasi Survey dan Pemetaan Nasional, 2006.

Khazin, Muhyiddin, Ilmu Falak dalam Teori dan Praktek, Yogyakarta: Buana Pustaka, Cet. Ke-1, 2004.

Press, 2009.

, Muhyiddin, Kamus Ilmu Falak, Jogjakarta: Buana Pustaka, Cet. Ke-1, 2005.

, Muhyiddin, 99 Tanya Jawab Masalah Hisab dan Rukyat, Yogyakarta: Ramadhan

Partanto, Pius A., dan M. Dahlan Al Barry, Kamus Ilmiah Populer, Surabaya: Arkola, 1994.

Radiman, Iratius, dkk, Ensiklopedi Singkat Astronomi dan Ilmu Yang Bertautan, Bandung: Penerbit ITB, 1980.

Ruskanda, Farid, 100 Masalah HIsab dan Rukyat Telaah Syariah, Sains, dan Teknologi, Jakarta: Gema Insani Press, 1996.

Shadiq, Sriyatin, Perkembangan Hisab Rukyah dan Penetapan Awal Bulan Qamariah, dalam Muamal Hamidy (Editor), Mепијu Kesatuan Hari Raya, Surabaya: Bina Ilmu, 1995.

Supriatna, Encup, Hisab Rukyah dan Aplikasinya (Buku Satu), Bandung: Refika Aditama, Cet. Ke-1, 2007.

Wawancara dengan Dr. Ing. Khafid di Kantor Pascasarjana UIN Walisongo Semarang pada 8 Mei 2010.

Wawancara dengan Dr. Ing. Khafid di Hotel Nalendra Cihampelas Bandung pada tanggal 28 Juli 2010.

Wawancara dengan Dr. Ing. Khafid via Email pada 12 Oktober 2010.

\section{Website}

http://www.eramuslim.com/syariah/ilmu-hisab/posisi-matahari-algoritma-meeus.htm.

Diakses pada 9 Desember 2010.

http://prisdaba.blogspot.com. Diakses pada 9 Desember 2010. 